\title{
Production of organic fertilizer based on sewage sludge cultivated with grass under an aeration system ${ }^{1}$
}

\author{
Paulo Henrique Silveira Cardoso ${ }^{2 * \mathbb{D}}$, Paula Wellen Barbosa Gonçalves ${ }^{3}$, Gustavo de Oliveira Alves ${ }^{4}$, \\ Rodinei Facco Pegoraro ${ }^{4}$, Regynaldo Arruda Sampaio ${ }^{4}$
}

10.1590/0034-737X202168050012

\begin{abstract}
The cultivation of grasses in sewage sludge (SS) with aeration has the potential for stabilization of sludge organic matter in the production of organic fertilizer. Thus, the objective of this work was to evaluate the cultivation of Urochloa brizantha and Pennisetum purpureum under aerated system on the chemical and biological attributes of SS to obtain a matured organic fertilizer. The study was conducted in a randomized block design in a $2 \times 2+2$ factorial scheme with four replications. Factors consisted of cultivation of $P$. purpureum or $U$. brizantha in SS, with or without intermittent aeration. Control treatments were SS without cultivation, with or without aeration. Sewage sludge was collected in layers and the chemical and microbial attributes were evaluated. There was no significant difference between treatments for grass dry matter. The $\mathrm{C} / \mathrm{N}$ ratio was not matched with organic fertilizer stabilization due to similar losses of $\mathrm{C}$ and $\mathrm{N}(\sim 7 \%)$. However, microbial activity was reduced in the presence of plant cultivation demonstrating improvement in the properties of the organic fertilizer produced. Through uni- and multivariate analysis, organic fertilizer produced from SS aerated and cultivated with $P$. purpureum showed matured organic matter.
\end{abstract}

Keywords: biodegradation; biosolid; organic matter; residue recycling.

\section{INTRODUCTION}

The high volume of sewage sludge (SS) produced at the wastewater treatment plants (WWTP) has burdened the disposal of this waste in landfills, since its management may reach $60 \%$ of the operating costs of a WWTP (Godoy, 2013). An economically and environmentally alternative would be the disposal of SS in farming and forestry areas as a conditioner of the soil and/or organic fertilizer, therefore improving the physical, chemical and biological characteristics of the soil, as the SS has considerable concentration of nutrient and organic matter (Tontti et al., 2017; Melo et al., 2018).

However, SS may contain contaminants such as heavy metals (Oliveira et al., 2018), toxic organic compounds (Alvarenga et al., 2017), and pathogens (Oliveira et al., 2019). In addition, it may not present stabilized organic matter, therefore, it needs some technique for its maturation. In Brazil, the agricultural and forestry use of SS is regulated by the National Council of the Environment (Conselho Nacional do Meio Ambiente - CONAMA) thought the resolution 498/2020 (Brasil, 2020a). This resolution establishes limits of heavy metal and pathogens organisms, classifying the SS, where, in which culture, and how it can be applied. And there are suggestions of how the organic matter of SS can be stabilized and contaminants reduced.

As an alternative, the SS cultivation technique would provide rapid stabilization of organic matter and degradation of toxic organic compounds (Alvarenga et al., 2017). With this technique, studies reported that Pennisetum purpureum had a great development cultivated directly in SS (Alvarenga et al., 2018); phytoextracted As (Alvarenga et al., 2019); reduced Zn concentration bound

\footnotetext{
Submitted on December 23 $3^{\text {th }}, 2019$ and accepted on March 14 $4^{\text {th }}, 2021$.

${ }^{1}$ This work is part of the first author's Master Dissertation.

${ }^{2}$ Universidade de São Paulo, Centro de Energia Nuclear na Agricultura, Piracicaba, São Paulo, Brazil. paulohscardoso@usp.br

${ }^{3}$ Universidade Estadual Paulista, Campus Jaboticabal, Jaboticabal, São Paulo, Brazil. paulawellen@ hotmail.com

${ }^{4}$ Universidade Federal de Minas Gerais, Instituto de Ciências Agrárias, Montes Claros, Minas Gerais, Brazil. gustavo.go83@gmail.com; rodinei_pegoraro@yahoo.com.br; regynaldo@terra.com.br

*Corresponding author: paulohscardoso@usp.br
} 
to organic matter and increased residual $\mathrm{Zn}$ (Oliveira et al., 2018); and reduced chlorobenzenes concentration in the SS after 150 days of cultivation (Alvarenga et al., 2017).

Based on that, the cultivation of Pennisetum purpureum and Urochloa brizantha in SS presents potential due to the rusticity of these grasses, their fasciculated root system, and adequate efficiency in atmospheric $\mathrm{CO}_{2}$ fixation for plant biomass production (Silva et al., 2005; Flores et al., 2012). In addition, scientific studies report the phytoremediation potential of $\mathrm{Zn}, \mathrm{Cd}$ (Zhang et al., 2010) and Cs (Kang et al., 2012) for $P$. purpureum and picloran for U. brizantha (Braga et al., 2016).

Another factor that may contribute to reducing the presence of contaminants and stabilization of organic matter would be SS aeration during cultivation. This process is known as aerated static pile composting, where the organic waste is disposed on a perforated air injection pipe, with no need for material revolving (Ekinci et al., 2017). With this process, studies have reported a reduction of the toxic potential of heavy metals (Cai et al., 2007a; Golbaz et al., 2020) and removal of polycyclic aromatic hydrocarbons (Cai et al., 2007b) in sewage sludge.

The hypothesis of this study is that the cultivation of grass in sewage sludge intercropped with its aeration may stabilize the organic matter of the SS, providing the production of a better-quality organic fertilizer. Thus, the objective was to evaluate the interference of the cultivation of $P$. purpureum $U$. brizantha under an aerated system on chemical and biological attributes of SS to obtain a matured organic fertilizer.

\section{MATERIAL AND METHODS}

The experiment was conducted at the Institute of Agricultural Sciences (Instituto de Ciências Agrárias - ICA) of the Universidade Federal de Minas Gerais (UFMG), Montes Claros campus, from November 2016 to January 2017. According to the Köppen's classification, the predominant climate in the region is the Aw - tropical savannah with rainy summer and dry winter. Rainfall of $253 \mathrm{~mm}$ and maximum and minimum temperatures of 32.2 and $20.7^{\circ} \mathrm{C}$ were recorded over the experiment period, respectively (INMET, 2017).

The study was carried out in a randomized block design and four replications, in a $2 \times 2+2$ factorial scheme, consisting of two plant cultivations, with $P$. purpureum $U$. brizantha cv. Marandu (planting density of 50 plants per $\left.\mathrm{m}^{2}\right)$, combined with the absence or presence of aeration $\left(0.14 \mathrm{~m}^{3} \mathrm{~min}^{-1} \mathrm{~m}^{-3}\right)$ of sewage sludge. The two additional treatments corresponded to the presence or absence of sewage sludge aeration without the cultivation of plants in the SS. The experimental plots, made up of 0.7 x 0.7 x $0.55 \mathrm{~m}$ maideirits boxes, were filled up to $0.5 \mathrm{~m}$ high with sewage sludge from WWTP-Vieira, Montes Claros-MG.

It can be found in that plant, reactors in which the anaerobic biological treatment of sewage is performed. Next, the wastewater from these reactors goes to aerobic biological filters. In the final stage of sewage treatment, the decantation process takes place, and the water can be discharged to the watercourse. The sewage sludge is centrifuged and thermally dried at $350{ }^{\circ} \mathrm{C}$ for $30 \mathrm{~min}(6-$ $8 \%$ humidity). As the composition of sewage sludge may vary depending on different periods of the year, characterization analyses of the byproduct were performed before the experiment was set up (Table 1). The concentration of the heavy metal detected $(\mathrm{Cu}, \mathrm{Zn}$, and $\mathrm{Pb}$ ) by the analysis was lower than the maximum concentration established by the CONAMA resolution 498 (Brasil, 2020a).

The aeration system consisted of a 1.5-hp, 1,150-rpm engine and a sirocco fan with a flow rate of $2.7 \mathrm{~m}^{3} \mathrm{~min}^{-1}$. The fan outlet was adapted and branched into $0.5 \mathrm{~mm} \mathrm{x}$ $0.35 \mathrm{~m}$ fork-shaped $25 \mathrm{~mm}$-PVC pipes with 12 holes of 10 $\mathrm{mm}$ diameter, spaced by $0.08 \mathrm{~m}$, at the bottom of the experimental plots and covered by a shade screen to avoid clogging the holes. The aerated experimental plots received intermittent ( $30 \mathrm{~min}$ on/off) airflow of $0.14 \mathrm{~m}^{3} \mathrm{~min}^{-1}$ per $\mathrm{m}^{3}$ of sewage sludge, obtained according to the power and flow of the ventilation system. This flow was regulated with the aid of an anemometer and a ball valve at the entrance of the air of the plot.

$P$. purpureum was planted by using $10-\mathrm{cm}$ long cuttings containing a bud. The planting of $U$. brizantha was done by using seedlings produced in commercial substrate, as the seeds did not show proper germination and uniformity when planted directly in the sewage sludge, in a previous test. Both grasses were planted with $0.14 \times 0.14 \mathrm{~m}$ spacing at $0.05 \mathrm{~m}$ depth, with a density of 50 plants per $\mathrm{m}^{2}$, totaling 25 plants per plot. Plots were irrigated over cultivation with supply water to keep moisture close to the field capacity ( $26 \%$ of the volumetric humidity).

After 90 days of grass cultivation, when $U$. brizantha began to emit inflorescence, the four central plants of the plot were collected and separated into aerial part and roots, in order to estimate dry matter production. And samples of sewage sludge in the layers 0-10, 10-20, 20-30, 30-40 and $>40 \mathrm{~cm}$ were collected. The plant and SS samples were dried in an air forced circulation oven at $65^{\circ} \mathrm{C}$ until constant weight, with the determination of the dry mass of the plant parts.

The following analyses were carried out in SS samples: $\mathrm{pH}$ in $\mathrm{CaCl}_{2} 0.01 \mathrm{~mol} \mathrm{~L}^{-1}$, organic $\mathrm{C}$, total $\mathrm{N}$, cation exchange capacity (CEC), and calculations of $\mathrm{C} / \mathrm{N}$ and $\mathrm{CEC} / \mathrm{C}$ ratios (Alcarde, 2009); microbial activity through the method of 
basal (BR) and cumulated respirometric $(\mathrm{CR})$ rate (Silva et al., 2007a); microbial biomass carbon (MBC) (Silva et al., 2007b), with a Kc value of 0.197 (Sparling \& West, 1988); and calculation of metabolic $\left(\mathrm{qCO}_{2}\right)$ and microbial (qMIC) quotients (Silva et al., 2007a, b).

The data obtained from the grass analyses were submitted to the confidence interval test at $5 \%$ probability. The use of analysis of variance, in this case, was not possible because of the low number of experimental units, below 20, as suggested in the literature (Pimentel-Gomes, 2009). The data obtained from the sewage sludge analyses were subjected to analysis of variance, with treatment unfolding in orthogonal contrasts, by applying the $\mathrm{F}$ test at 0.05 probability. Contrasts were determined to compare treatments with and without cultivation $(\mathrm{C} 1)$, the presence and absence of aeration in uncultivated SS (C2), the cultivation of $U$. brizantha and $P$. purpureum in sewage sludge (C3), the presence and absence of aeration of sewage sludge cultivated with $U$. brizantha $(\mathrm{C} 4)$ and the presence and absence of aeration of sewage sludge cultivated with $P$. purpureum (C5). For the $0-50 \mathrm{~cm}$ layer, the Tukey multiple comparison test $(p \leq 0.05)$ was performed. Correlation analysis was performed by using Pearson's test $(p \leq 0.05)$. For these analyses, software RStudio (R Core Team, 2017) was used. Multivariate analysis was performed through principal component and cluster methods, with the aid of SAS software (SAS Institute Inc., 2002).

\section{RESULTS AND DISCUSSION}

\section{Production of $P$. purpureum and $U$. brizantha grown in sewage sludge}

Production of the dry matter of the aerial part (DMAP), root (DMR) and total (DMT) of $P$. purpureum and $U$. brizantha were similar between treatments with or without aeration in sewage sludge after 90 days of cultivation (Table 2). However, the DMR of $P$. purpureum was 2.1fold greater than that of $U$. brizantha. The higher volume of $P$. purpureum roots may represent higher tolerance of the grass to sewage sludge contaminants and to the rise in substrate temperature in the initial phase of cultivation. The average total biomass of $P$. purpureum corresponded to $68 \mathrm{~g}$ per plant, with a density of 50 plants per $\mathrm{m}^{2}$, were considered lower than that obtained by Oliveira et al. (2018), who found a total biomass of $150 \mathrm{~g}$ per plant, with a density of 25 plants per $\mathrm{m}^{2}$, at 90 days of cultivation in sewage sludge.

\section{Chemical attributes of cultivated sewage sludge}

The $\mathrm{pH}$ of the SS was reduced when cultivated (C1) with $P$. purpureum (C3) and in the presence of aeration (C5) compared to without cultivation, cultivated with $U$. brizantha and without aeration, respectively (Table 3). $\mathrm{SS}$ acidification in these treatments was related to the release of $\mathrm{H}^{+}$ions through degradation of organic matter and $\mathrm{N}$ nitrification by microorganisms during the SS stabilization process and through exudation of organic acids by plants (Souza et al., 2012; Villanueva et al., 2012), especially in aeration treatments. The difference between treatments was more evident for WANC and WAPP, where this treatment had $0.31 \mathrm{pH}$ units lower than WANC (Table 3 ). This result reinforces the hypothesis of the importance of grass cultivation in the SS stabilization process, especially the P. purpureum. Shen et al. (2001) observed

Table 2: Dry matter of the aerial part (DMAP), root (DMR) and total (DMT) of $P$. purpureum and $U$. brizantha grown in sewage sludge

\begin{tabular}{lccc}
\hline \multirow{2}{*}{ Treat. } & DMAP & DMR & DMT \\
\cline { 2 - 4 } & \multicolumn{3}{c}{ g per plant } \\
\hline WAPP & $49.3 \pm 22.7$ & $22.2 \pm 12.4$ & $71.5 \pm 20.7$ \\
NAPP & $43.6 \pm 33.6$ & $20.1 \pm 10.4$ & $63.7 \pm 26.9$ \\
WAUB & $35.6 \pm 37.3$ & $9.5 \pm 4.5$ & $45.1 \pm 24.9$ \\
NAUB & $51.7 \pm 30.2$ & $10.5 \pm 5.2$ & $62.3 \pm 21.0$ \\
\hline
\end{tabular}

Averages followed by confidence interval $(p \leq 0.05)$. Treat. Treatments; WAPP - SS aerated and cultivated with $P$. purpureum; NAPP - SS non-aerated and cultivated with $P$. purpureum; WAUB - SS aerated and cultivated with $U$. brizantha; NAUB - SS nonaerated and cultivated with $U$. brizantha.

Table 1: Initial chemical and biological characterization of sewage sludge

\begin{tabular}{lcrllrlrr}
\hline Attributes & Unity & Value & Attributes & Unity & Value & Attributes & Unity & Value \\
\hline $\mathrm{pH} \mathrm{CaCl}$ & - & 5.9 & $\mathrm{P}$ & $\mathrm{g} \mathrm{kg}^{-1}$ & 7.8 & $\mathrm{Mn}$ & $\mathrm{mg} \mathrm{kg}^{-1}$ & 120.0 \\
$\mathrm{OC}$ & $\mathrm{g} \mathrm{kg}^{-1}$ & 323.0 & $\mathrm{~K}$ & $\mathrm{~g} \mathrm{~kg}^{-1}$ & 4.0 & $\mathrm{Ni}$ & $\mathrm{mg} \mathrm{kg}^{-1}$ & 23.0 \\
Total N & $\mathrm{g} \mathrm{kg}^{-1}$ & 32.0 & $\mathrm{Ca}$ & $\mathrm{g} \mathrm{kg}^{-1}$ & 10.3 & $\mathrm{~Pb}$ & $\mathrm{mg} \mathrm{kg}^{-1}$ & 31.0 \\
$\mathrm{CEC}$ & $\mathrm{mmol} \mathrm{kg}^{-1}$ & 916.0 & $\mathrm{Mg}$ & $\mathrm{g} \mathrm{kg}^{-1}$ & 1.6 & $\mathrm{BR}$ & $\mathrm{mg} \mathrm{kg} \mathrm{h}^{-1}$ & 3.8 \\
$\mathrm{OM}$ & $\mathrm{g} \mathrm{kg}^{-1}$ & 572.0 & $\mathrm{Fe}$ & $\mathrm{mg} \mathrm{kg}$ & $3,075.0$ & $\mathrm{CR}$ & $\mathrm{mg} \mathrm{kg}^{-1}$ & 68.0 \\
$\mathrm{TMW}$ & $\mathrm{g} \mathrm{kg}^{-1}$ & 428.0 & $\mathrm{Na}$ & $\mathrm{mg} \mathrm{kg}$ & 618.0 & $\mathrm{MBC}$ & $\mathrm{mg} \mathrm{kg}^{-1}$ & $10,715.0$ \\
$\mathrm{C} / \mathrm{N}$ & - & 10.0 & $\mathrm{Zn}$ & $\mathrm{mg} \mathrm{kg}$ & 283.0 & $\mathrm{qMIC}$ & $\%$ & 3.3 \\
$\mathrm{CEC} / \mathrm{C}$ & - & 28.0 & $\mathrm{Cu}$ & $\mathrm{mg} \mathrm{kg}$ & 112.0 & $\mathrm{qCO}$ & $\mathrm{mg} \mathrm{g}^{-1} \mathrm{MBC} \mathrm{h}^{-1}$ & 0.3
\end{tabular}

OC - Organic carbon; CEC - Cation exchange capacity; OM - Organic matter; TMW - Total mineral waste; BR - Basal respiration; $\mathrm{h}$ - Hour; CR - Cumulative respiration; MBC - Microbial biomass carbon; qMIC - Microbial quotient; $\mathrm{qCO}_{2}-\mathrm{Metabolic}_{\mathrm{Cuotient}} \mathrm{Cr}$ was detected $\left(<1.25 \mathrm{mg} \mathrm{L}^{-1}\right) ; \mathrm{Ba}, \mathrm{Cd}$, and Mo weren't detected. 
Table 3: $\mathrm{pH}_{\text {in } \mathrm{CaCl}_{2}} 0.01 \mathrm{~mol} \mathrm{~L}^{-1}$ and organic carbon of sewage sludge cultivated with P. purpureum or $U$. brizantha, with or without aeration

$\mathrm{pH}$ in $\mathrm{CaCl}_{2} 0.01 \mathrm{~mol} \mathrm{~L}^{-1}$

Organic

Treataments / Contrasts

\begin{tabular}{llllll}
\hline $0-10$ & $10-20$ & $20-30$ & $30-40$ & $>40$ & $0-50$
\end{tabular}

\begin{tabular}{llllllllll} 
& \multicolumn{10}{c}{$\mathbf{c m}$} \\
\cline { 2 - 5 } & 6.32 & 6.31 & 6.32 & 6.29 & 6.13 & 6.28 a & 298 & 305 & 274 \\
WANC & 6.19 & 6.20 & 6.17 & 6.21 & 6.12 & 6.18 ab & 271 & 293 & 291
\end{tabular}

$\begin{array}{llll}\text { NANC } & 6.19 & 6.20 & 6.17\end{array}$

$\begin{array}{llll}\text { WAPP } & 5.84 & 5.91 & 5.94\end{array}$

$\begin{array}{llll}\text { NAPP } & 6.19 & 6.11 & 6.08\end{array}$

$\begin{array}{llll}\text { WAUB } & 6.10 & 6.04 & 6.29\end{array}$

NAUB

$\begin{array}{lll}6.19 & 6.18 & 6.13\end{array}$

$\begin{array}{lll}6.21 & 6.12 & 6.18 \mathrm{ab}\end{array}$

$\begin{array}{llll}298 & 305 & 274 & 283\end{array}$

$>40 \quad 0-50$

$\begin{array}{lll}6.16 & 6.08 & 6.15 \mathrm{ab}\end{array}$

\begin{tabular}{llccc}
\hline $\mathrm{C}_{1}=\mathrm{NS}-\mathrm{CS}$ & $0.70^{*}$ & $0.78^{*}$ & $\mathrm{~ns}$
\end{tabular}

$\begin{array}{lcccc}\mathrm{C}_{2}=\text { WANC - NANC } & 0.70 & 0.78^{*} & \mathrm{~ns}^{2} & \mathrm{~ns} \\ \mathrm{~ns} & \mathrm{~ns} & \mathrm{~ns} & \mathrm{~ns}\end{array}$

$\mathrm{C}_{3}=\mathrm{PP}-\mathrm{UB}$

$\mathrm{C}_{4}=$ WAPP - NAPP

$\frac{\mathrm{C}_{5}=\text { WAUB }-\mathrm{NAUB}}{\mathrm{CV}(\%)}-0.09^{*}$

$3.70 \quad 4.24$

$4.24 \quad 1.85$

858.38

$\mathrm{C}_{1}, \mathrm{C}_{2}, \mathrm{C}_{3}, \mathrm{C}_{4}$ e $\mathrm{C}_{5}$ - Contrasts 1, 2, 3, 4, and 5, respectively; NS - Non-cultivated SS (WANC; NANC); CS - Cultivated SS (WAPP; NAPP; WAUB; NAUB); WANC - SS aerated and non-cultivated; NANC - SS non-aerated and non-cultivated; PP - SS cultivated with P. purpureum (WAPP; NAPP); UB - SS cultivated with $U$. brizantha (WAUB; NAUB); WAPP - SS aerated and cultivated with $P$. purpureum; NAPP - SS non-aerated and cultivated with P. purpureum; WAUB - SS aerated and cultivated with U. brizantha; NAUB - SS non-aerated and cultivated with $U$. brizantha.; CV - Coefficient of variation; ns - Not significant at 0.05 probability by $\mathrm{F}$ test; *,** - Significant at 0.05 and 0.01 probability by $\mathrm{F}$ test, respectively. Average values followed by the same letter are not significant at 0.05 probability by Tukey test. 
that $P$. purpureum can exudate organic acids, such as oxalic acid, citric acid, pentanedioic acid, and phthalic acid, leading to a acidification of the rhizosphere zone.

The cultivation (C1) of P. purpureum (C3) with aeration (C4) increased the organic $\mathrm{C}$ (OC) concentration in the sewage sludge (Table 3 ). Also, in the 0-50 cm layer, WAPP increased by 6.9 and $7.3 \%$ the OC concentration in the SS in comparison to WAUB and NANC treatments, respectively. These results were attributed to the higher cycling capacity of organic compounds in the grass root system (Costa et al., 2009) and the microbial efficiency in the conversion rate of SS carbon into stabilized organic compounds in aeration treatment, corroborating with the results of $\mathrm{pH}$ and higher root production by $P$. purpureum.

The presence of root system of plants, mainly $P$. purpureum, and aeration contributed to the increase of biological activity, leading to greater degradation of organic matter from sewage sludge. This could be related to the liberation of exudates in the substrate, enhancing microbial diversity and activity (Shen et al., 2001; Carvalhais et al., 2011). The most pronounced effect of $P$. purpureum may be due to the association of its roots with Enterobacter and Pantoea agglomerans, which act intensely in the degradation of humic substances and even toxic substances, such as polycyclic aromatic hydrocarbons (Videira et al., 2012; Li et al., 2015, 2016; Chikere \& Fenibo, 2018; Umar et al., 2018).

As a consequence, there was an average reduction by $7.4 \%$ in the OC concentration at the end of cultivation in relation to the initial sewage sludge (Table 1). But it was smaller in relation to other SS stabilization processes, with a reduction by $19 \%$ in revolving piles (Moretti et al., 2015) and 10-25\% in biological reactors (Yuan et al., 2016; Awasthi et al., 2018). However, the OC concentration obtained in this study is greater than the minimum threshold of $150 \mathrm{~g} \mathrm{~kg}^{-1}$, established for the production and commercialization of organic fertilizer by the Ministry of Agriculture, Livestock and Supply (MAPA) in Normative Instruction (NI) No. 61 (Brasil, 2020b).

Nitrogen concentration in the sewage sludge was not influenced by the treatments $(p>0.05)$, however, a higher $\mathrm{N}$ concentration was found in the grass treatments $(\mathrm{C} 1$; Table 4), showing that they were able to maintain the $\mathrm{N}$ concentration in the SS. This may also be related to $\mathrm{N}$ uptake by root recycling and the association of grasses with bacteria capable of absorbing atmospheric $\mathrm{N}$ and incorporating it into sewage sludge, as observed by Silva et al. (2013) for U. brizantha and by Morais et al. (2012) for $P$. purpureum. Nitrogen losses caused by volatilization or leaching by the processes proposed in this work reached levels below composting in biological reactors, where a reduction by 16 to $23 \%$ in $\mathrm{N}$ concentration may occur (Yuan et al., 2016; Awasthi et al., 2018). Also, NI 61 states that the minimum concentration of $\mathrm{N}$ in organic fertilizer should be $5 \mathrm{~g} \mathrm{~kg}^{-1}$ (Brasil, 2020b), however, at the end of cultivation, an average concentration of $29.8 \mathrm{~g} \mathrm{~kg}^{-1}$ was obtained.

The cation exchange capacity (CEC) was influenced by grass cultivation treatments $(\mathrm{C} 1)$, however, no difference was observed between treatments in the 0-50 $\mathrm{cm}$ layer (Table 4). Higher CEC values in cultivation treatments represent greater stability of sewage sludge organic matter (Zhang \& Sun, 2016). The CEC showed a moderate and positive correlation with the $\mathrm{OC}(\mathrm{r}=0.54 ; p$ $<0.05)$ and $\mathrm{N}(\mathrm{r}=0.49 ; p<0.05)$ concentration in the SS (Figure 1). This correlation is related to the negative charges existing in the $\mathrm{C}$ and $\mathrm{N}$ groups, such as carboxylic, esters, amines, amides, among others (Sanchez-Monedero et al., 2018). It can explain the average reduction of $2.4 \%$ in the initial sewage sludge CEC (Table 1), due to the decrease in $\mathrm{OC}$ and $\mathrm{N}$ concentrations. However, it is noticed that this reduction was smaller than the losses in OC and $\mathrm{N}$ concentration ( $7 \%)$, therefore, evidencing the formation of new functional groups, responsible for the bindings between negative charges of the surface of the cation sites (Sanchez-Monedero et al., 2018).

The CEC/C ratio was negatively correlated $(\mathrm{r}=-0.62 ; p$ $<0.05$ ) with the $\mathrm{C} / \mathrm{N}$ ratio (Figure 1 ), so the lower the $\mathrm{C} / \mathrm{N}$ ratio, the higher the $\mathrm{CEC} / \mathrm{C}$ ratio of the $\mathrm{SS}$, a condition that expresses a higher degree of maturity and stability of the organic fertilizer produced (Moretti et al., 2015). No difference was found between treatments for $\mathrm{C} / \mathrm{N}$ ratio; however, the contrasts showed greater SS stability in treatments without cultivation $(\mathrm{C} 1)$, with $U$. brizantha cultivation (C3) and without aeration (C5; Table 5). Neither there were significant changes in this index compared to the initial sewage sludge (Table 1). This is the result of the equivalent losses of $\mathrm{OC}$ and $\mathrm{N}(\sim 7 \%)$ that occurred at the end of grass cultivation, so the $\mathrm{C} / \mathrm{N}$ ratio was not effective in evaluating the stability of the organic fertilizer produced. Even so, the values obtained in this work (average of 10.2) are below the maximum threshold of 20, established by IN 61 to obtain stabilized organic fertilizer (Brasil, 2020b).

The $\mathrm{CEC} / \mathrm{C}$ ratio was higher in the treatments in which sewage sludge was cultivated with $U$. brizantha $(\mathrm{C} 3)$ with aeration (C5) and P. purpureum without aeration (C4; Table $5)$, showing greater stability in these systems. At the end of cultivation, organic fertilizer obtained an average $\mathrm{CEC} /$ $\mathrm{C}$ ratio of 29.9, corresponding to an increase of $5.3 \%$ compared to that of the initial sewage sludge (Table 1). Lima et al. (2009) established a minimum CEC/C ratio of 17 for mature compost. An average of $76 \%$ higher than the recommended was obtained in this study. This index was more satisfactory compared to $\mathrm{C} / \mathrm{N}$ ratio to determine the stability of organic fertilizer, due to the perception of changes in organic matter loads per OC concentration. 
Table 4: Total N and cation exchange capacity of sewage sludge cultivated with P. purpureum or U. brizantha, with or without aeration

\begin{tabular}{|c|c|c|c|c|c|c|c|c|c|c|c|c|}
\hline \multirow{3}{*}{ Treataments / Contrasts } & \multicolumn{6}{|c|}{ Total N $\left(\mathrm{g} \mathrm{kg}^{-1}\right)$} & \multicolumn{6}{|c|}{ Cation Exchange Capacity $\left(\mathrm{mmol}_{\mathrm{c}} \mathrm{kg}^{-1}\right)$} \\
\hline & $0-10$ & $10-20$ & $20-30$ & $30-40$ & $>40$ & $0-50$ & $0-10$ & $10-20$ & $20-30$ & $30-40$ & $>40$ & $0-50$ \\
\hline & \multicolumn{12}{|c|}{$\mathrm{cm}$} \\
\hline WANC & 29.5 & 29.4 & 29.2 & 29.2 & 28.4 & $29.1 \mathrm{a}$ & 918 & 909 & 870 & 886 & 860 & $889 \mathrm{a}$ \\
\hline NANC & 28.7 & 28.6 & 28.0 & 28.7 & 27.7 & $28.3 \mathrm{a}$ & 873 & 878 & 858 & 831 & 842 & $856 \mathrm{a}$ \\
\hline WAPP & 29.1 & 29.2 & 29.0 & 31.5 & 32.1 & $30.2 \mathrm{a}$ & 912 & 925 & 921 & 877 & 872 & $901 \mathrm{a}$ \\
\hline NAPP & 30.1 & 29.6 & 29.9 & 30.3 & 31.5 & $30.3 \mathrm{a}$ & 945 & 912 & 850 & 865 & 889 & $892 \mathrm{a}$ \\
\hline WAUB & 29.7 & 29.9 & 30.2 & 30.9 & 30.7 & $30.3 \mathrm{a}$ & 932 & 918 & 885 & 904 & 912 & $910 \mathrm{a}$ \\
\hline NAUB & 30.3 & 29.8 & 30.3 & 32.8 & 31.0 & $30.9 \mathrm{a}$ & 946 & 884 & 918 & 900 & 915 & $913 \mathrm{a}$ \\
\hline Average & 29.6 & 29.4 & 29.5 & 30.6 & 30.2 & 29.9 & 921 & 904 & 884 & 877 & 882 & 894 \\
\hline $\mathrm{C}_{1}=\mathrm{NS}-\mathrm{CS}$ & $\mathrm{ns}$ & $\mathrm{ns}$ & $\mathrm{ns}$ & $-9.7^{*}$ & $-13.1^{*}$ & $-6.9^{*}$ & $\mathrm{~ns}$ & $\mathrm{~ns}$ & $\mathrm{~ns}$ & $\mathrm{~ns}$ & $-184^{*}$ & $-126^{*}$ \\
\hline $\mathrm{C}_{2}=\mathrm{WANC}-\mathrm{NANC}$ & ns & ns & ns & ns & ns & ns & ns & ns & ns & ns & ns & ns \\
\hline $\mathrm{C}_{3}=\mathrm{PP}-\mathrm{UB}$ & ns & ns & ns & ns & ns & ns & ns & ns & ns & ns & ns & ns \\
\hline $\mathrm{C}_{4}=\mathrm{WAPP}-\mathrm{NAPP}$ & ns & ns & ns & ns & ns & ns & $\mathrm{ns}$ & ns & $\mathrm{ns}$ & $\mathrm{ns}$ & ns & ns \\
\hline $\mathrm{C}_{5}=\mathrm{WAUB}-\mathrm{NAUB}$ & $\mathrm{ns}$ & $\mathrm{ns}$ & ns & $\mathrm{ns}$ & ns & $\mathrm{ns}$ & ns & $\mathrm{ns}$ & ns & ns & ns & ns \\
\hline CV $(\%)$ & 4.29 & 4.44 & 6.18 & 8.69 & 10.19 & 5.52 & 6.00 & 4.23 & 5.77 & 4.96 & 4.81 & 3.81 \\
\hline
\end{tabular}

$\mathrm{C}_{1}, \mathrm{C}_{2}, \mathrm{C}_{3}, \mathrm{C}_{4} \mathrm{e}_{5}-\mathrm{C}_{5}$ - SS non-aerated and non-cultivated, PP - SS cultivated with P. purpureum (WAPP; NAPP); UB - SS cultivated with U. brizantha (WAUB; NAUB); WAPP - SS aerated and cultivated with P. purpureum; NAPP - SS non-aerated and cultivated with $P$. purpureum; WAUB - SS aerated and cultivated with $U$. brizantha; NAUB - SS non-aerated and cultivated with $U$. brizantha.; CV - Coefficient of variation; ns - Not significant at 0.05 probability by F test; *, ** - Significant at 0.05 and 0.01 probability by F test, respectively. Average values followed by the same letter are not significant at 0.05 probability by Tukey test. 


\section{Microbial attributes in cultivated sewage sludge}

There was no significant effect of contrasts and between treatments for basal (BR) and cumulative (CR) respiration, however, a reduction of 48 and $57 \%$ was found in BR and CR (Table 6), respectively, at the end of cultivation compared the initial sewage sludge (Table 1). This result reflects the high maturation of the sewage sludge OM due to the reduction in microbial activity. The decrease in microbial activity, demonstrated in this work through the reduction of $\mathrm{CO}_{2}$ evolution, indicates greater stability of the produced fertilizer at the end of the cultivation period (Nikaeen et al., 2015), therefore, it is an important index in determining compost maturation.

The microbial biomass carbon (MBC) was higher in the treatments cultivated (C1) with $P$. purpureum $(\mathrm{C} 3)$ and $U$. brizantha without aeration (C5; Table 6). The presence of the root system, especially $P$. purpureum, may have increased microbial biomass through exudate release (Shen et al., 2001; Tian et al., 2017), favoring the decomposition of organic matter and stabilization of sewage sludge. This result is corroborated by the moderate negative correlation $(\mathrm{r}=-0.48 ; p<0.05)$ with the $\mathrm{C} / \mathrm{N}$ ratio (Figure 1), as the higher the microbial biomass, the lower the $\mathrm{C} / \mathrm{N}$ ratio. Moreover, there was a final reduction of $82 \%$ in MBC compared to the initial SS (Table 1), possibly due to the selection of microorganisms caused by the increased recalcitrance of humified organic matter (Alves et al., 2011).

The high coefficient of variation in the results of the basal and cumulative respiration and in the microbial biomass $\mathrm{C}$ (Table 6 ) are in consequence of the high organic matter concentration of the sewage sludge. The method used was developed to soil (Silva et al., 2007a, b), but it was adjusted to be used in this study and the results were as good as was expected for soil analysis.

The metabolic quotient $\left(\mathrm{qCO}_{2}\right)$ is an index that infers upon the efficiency of microorganisms in the use of $\mathrm{OC}$, that is, how much $\mathrm{C}$ is lost as $\mathrm{CO}_{2}$ per $\mathrm{C}$ incorporated microbial biomass, and the lower the value of $\mathrm{qCO}_{2}$, the higher the efficiency of microbial activity (Vieira \& Pazianotto, 2016). The $\mathrm{qCO}_{2}$ was lower in the $\mathrm{SS}$ aerated and non-cultivated treatment (C2), SS aerated and cultivated with $P$. purpureum (C4), and SS non-aerated and cultivated with $U$. brizantha (C5; Table 7). Thus, it can be inferred that the microorganisms showed higher efficiency in the use of $\mathrm{C}$ in the aerated sewage sludge, except when cultivated with $U$. brizantha. It could be explained by a more favorable environment for micro-

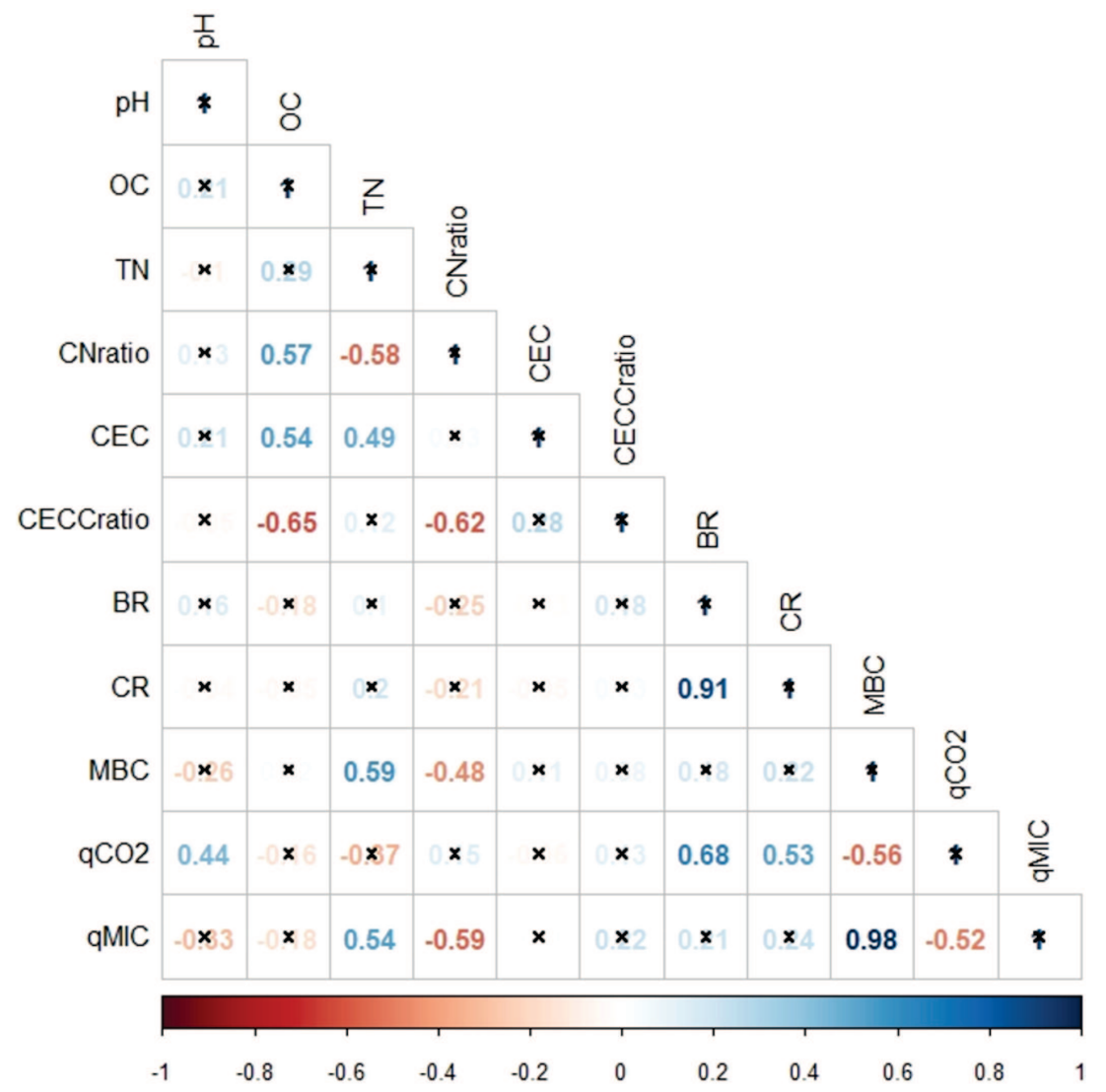

Figure 1: Pearson correlation between variables evaluated in sewage sludge after cultivation with $P$. purpureum and $U$. brizantha in the presence or absence of aeration Values with " $\mathrm{x}$ " were not significant at 0.05 probability by Pearson test. OC - Organic carbon; TN; Total Nitrogen; CEC - Cation Exchange Capacity; BR - Basal Respiration; CR - Cumulative Respiration; MBC - Microbial Biomass Carbon; qCO2 - Metabolic Quotient; qMIC - Microbial Quotient. 
Table 5: $\mathrm{C} / \mathrm{N}$ and $\mathrm{CEC} / \mathrm{C}$ ratios of sewage sludge cultivated with $P$. purpureum or $U$. brizantha, with or without aeration $\mathrm{C} / \mathrm{N}$ ratio CEC/C ratio

\begin{tabular}{|c|c|c|c|c|c|c|c|c|c|c|c|c|}
\hline \multirow{3}{*}{ Treataments / Contrasts } & & \\
\hline & $0-10$ & $10-20$ & $20-30$ & $30-40$ & $>40$ & $0-50$ & $0-10$ & $10-20$ & $20-30$ & $30-40$ & $>40$ & $0-50$ \\
\hline & \multicolumn{12}{|c|}{$\mathbf{c m}$} \\
\hline WANC & 10.3 & 10.8 & 9.2 & 9.6 & 11.0 & $10.2 \mathrm{a}$ & 31.9 & 29.8 & 32.3 & 30.5 & 26.8 & $30.1 \mathrm{a}$ \\
\hline NANC & 9.4 & 10.5 & 9.5 & 10.4 & 10.1 & $10.3 \mathrm{a}$ & 32.5 & 30.3 & 29.8 & 27.9 & 29.1 & $29.7 \mathrm{a}$ \\
\hline WAPP & 10.2 & 11.0 & 11.0 & 11.1 & 10.0 & $10.7 \mathrm{a}$ & 30.1 & 29.3 & 29.4 & 27.3 & 30.2 & $29.2 \mathrm{a}$ \\
\hline NAPP & 10.0 & 10.3 & 9.1 & 9.8 & 11.6 & $10.1 \mathrm{a}$ & 32.3 & 30.3 & 31.1 & 29.3 & 26.0 & $29.6 \mathrm{a}$ \\
\hline WAUB & 9.6 & 9.6 & 10.9 & 9.7 & 9.4 & $9.7 \mathrm{a}$ & 32.4 & 32.3 & 28.7 & 30.5 & 33.0 & $31.4 \mathrm{a}$ \\
\hline NAUB & 10.7 & 10.4 & 10.5 & 10.4 & 10.2 & $10.2 \mathrm{a}$ & 30.1 & 29.1 & 30.2 & 28.7 & 30.3 & $29.6 \mathrm{a}$ \\
\hline Average & 10.1 & 10.4 & 10.1 & 10.2 & 10.4 & 10.2 & 31.5 & 30.2 & 30.2 & 29.0 & 29.2 & 29.9 \\
\hline $\mathrm{C}_{1}=\mathrm{NS}-\mathrm{CS}$ & ns & $\mathrm{ns}$ & $-4.0^{*}$ & ns & ns & $\mathrm{ns}$ & $\mathrm{ns}$ & $\mathrm{ns}$ & $\mathrm{ns}$ & $\mathrm{ns}$ & ns & $\mathrm{ns}$ \\
\hline $\mathrm{C}_{2}=$ WANC - NANC & ns & ns & ns & ns & $\mathrm{ns}$ & $\mathrm{ns}$ & $\mathrm{ns}$ & $\mathrm{ns}$ & ns & $\mathrm{ns}$ & ns & $\mathrm{ns}$ \\
\hline $\mathrm{C}_{3}=\mathrm{PP}-\mathrm{UB}$ & ns & ns & $\mathrm{ns}$ & $\mathrm{ns}$ & $2.0^{*}$ & $\mathrm{~ns}$ & $\mathrm{~ns}$ & ns & $\mathrm{ns}$ & ns & $-7.1^{* *}$ & ns \\
\hline $\mathrm{C}_{4}=\mathrm{WAPP}-\mathrm{NAPP}$ & $\mathrm{ns}$ & $\mathrm{ns}$ & ns & ns & ns & $\mathrm{ns}$ & $\mathrm{ns}$ & $-1.0^{*}$ & $\mathrm{~ns}$ & $\mathrm{~ns}$ & ns & $-0.4^{*}$ \\
\hline $\mathrm{C}_{5}=$ WAUB - NAUB & $\mathrm{ns}$ & $\mathrm{ns}$ & $0.3^{*}$ & $-0.7^{*}$ & $-0.8^{*}$ & $\mathrm{~ns}$ & $\mathrm{~ns}$ & ns & $\mathrm{ns}$ & $\mathrm{ns}$ & $2.7^{*}$ & ns \\
\hline $\mathrm{CV}(\%)$ & 9.00 & 7.49 & 9.68 & 7.45 & 8.11 & 6.51 & 11.33 & 5.7 & 9.73 & 5.91 & 7.25 & 3.91 \\
\hline
\end{tabular}
$\mathrm{C}_{1}, \mathrm{C}_{2}, \mathrm{C}_{3}, \mathrm{C}_{4}$ e $\mathrm{C}_{5}$ - Contrasts 1, 2, 3, 4, and 5, respectively; NS - Non-cultivated SS (WANC; NANC); CS - Cultivated SS (WAPP; NAPP; WAUB; NAUB); WANC - SS aerated and noncultivated; NANC - SS non-aerated and non-cultivated; PP - SS cultivated with P. purpureum (WAPP; NAPP); UB - SS cultivated with $U$. brizantha (WAUB; NAUB); WAPP - SS aerated and cultivated with $P$. purpureum; NAPP - SS non-aerated and cultivated with P. purpureum; WAUB - SS aerated and cultivated with $U$. brizantha; NAUB - SS non-aerated and cultivated with $U$. brizantha.; CV - Coefficient of variation; ns - Not significant at 0.05 probability by $\mathrm{F}$ test; *, ** - Significant at 0.05 and 0.01 probability by $\mathrm{F}$ test, respectively. Average values followed by the same letter are not significant at 0.05 probability by Tukey test. 
organisms activity due to the aeration of the SS and the presence of roots, especially of the $P$. purpureum, since its $\mathrm{qCO}_{2}$ value tends to be lower than the other treatments. This result corroborates with those found for $\mathrm{pH}$ and $\mathrm{OC}$ (Table 3).

The microbial quotient (qMIC) index is used to infer the quality of $\mathrm{OM}$, since the higher its value, the higher the lability of $\mathrm{C}$, which is an appropriate environment for microbial growth (Vieira \& Pazianotto, 2016). The qMIC was higher in treatments with grass cultivation (C1) and $U$. brizantha cultivation and without aeration (C5) compared to without cultivation and with aeration of the sewage sludge, respectively (Table 7). However, the SS aerated and cultivated with $P$. purpureum showed a tendency to have higher qMIC values, corroborating to the previous results found in this study. Thus, these treatments showed favorable environment for microbial development for decomposition of organic matter and maturation of SS. A reduction of $81 \%$ of the initial sewage sludge (Table 1) was found at the end of cultivation, which may have occurred due to the increase of more humified and recalcitrant organic material, reducing the lability of $\mathrm{C}$.

\section{Multivariate analysis}

The dendrogram was obtained from the cluster analysis by the Ward method (Figure 2A). It was observed the formation of four groups through likelihood: 1) SS non-aerated and non-cultivated (NANC); 2) SS aerated and non-cultivated (WANC) and SS non-aerated and cultivated with $P$. purpureum (NAPP); 3) SS aerated and cultivated with $U$. brizantha (WAUB); and 4) SS nonaerated and cultivated with $U$. brizantha (NAUB) and SS aerated and cultivated with $P$. purpureum (WAPP). The analysis suggests the increasing order of treatments that provided improvements in the characteristics of the organic fertilizer produced from sewage sludge. Thus, our results confirming that the introduction of grasses and aeration, mainly $P$. purpureum, promoted an increase in sewage sludge quality when compared to without cultivation and aeration, in agreement to other studies performed evaluating the effect of these techniques separately (Cai et al., 2007a, b; Alvarenga et al., 2017, 2018, 2019; Golbaz et al., 2020). This result is also confirmed by univariate analysis, for example by microbial attributes (Tables 6 and 7), $\mathrm{pH}$, and OC (Table 3).

By analyzing the biplot graph, it can be observed that the first (PC1) and second (PC2) principal components together represent $80.6 \%$ of the total data variability (Figure $2 \mathrm{~B}$ ). It is also possible to determine which variables had the greatest influence on treatments in multivariate analysis. Based on that, the lower values of CEC, TN, qMIC, and MBC attributes provided poorer quality of noncultivated SS (NANC, WANC). For NAUB, the opposite was observed, where these same attributes were responsible for improving the characteristics of the SS in

Table 6: Basal (BR; $\left.\mathrm{mg} \mathrm{CO}_{2} \mathrm{~kg}^{-1} \mathrm{~h}^{-1}\right)$ and cumulative $\left(\mathrm{CR} ; \mathrm{mg} \mathrm{CO}_{2} \mathrm{~kg}^{-1}\right)$ respiration and microbial biomass of sewage sludge cultivated with $P$. purpureum or $U$. brizantha, with or without aeration

\begin{tabular}{|c|c|c|c|c|c|c|c|c|}
\hline \multirow{3}{*}{$\begin{array}{l}\text { Treataments / } \\
\text { Contrasts }\end{array}$} & \multirow{2}{*}{$\begin{array}{c}\text { BR } \\
0-50\end{array}$} & \multirow{2}{*}{$\frac{\text { CR }}{0-50}$} & \multicolumn{6}{|c|}{ Microbial biomass carbon (mg kg-1) } \\
\hline & & & $0-10$ & $10-20$ & 20-30 & $30-40$ & $>40$ & $0-50$ \\
\hline & \multicolumn{8}{|c|}{$\mathbf{c m}$} \\
\hline WANC & $1.70 \mathrm{a}$ & $23.0 \mathrm{a}$ & 1,432 & 1,075 & 1,947 & 1,818 & 2,830 & $1,820 \mathrm{a}$ \\
\hline NANC & $2.38 \mathrm{a}$ & $32.3 \mathrm{a}$ & 1,515 & 1,661 & 2,012 & 1,201 & 1,700 & $1,618 \mathrm{a}$ \\
\hline WAPP & $1.68 \mathrm{a}$ & $28.5 \mathrm{a}$ & 2,604 & 2,657 & 2,340 & 1,747 & 1,973 & $2,264 \mathrm{a}$ \\
\hline NAPP & $1.72 \mathrm{a}$ & $25.4 \mathrm{a}$ & 2,482 & 1,432 & 969 & 956 & 2,936 & $1,755 \mathrm{a}$ \\
\hline WAUB & $2.42 \mathrm{a}$ & $35.8 \mathrm{a}$ & 1,734 & 900 & 2,106 & 2,546 & 2,733 & $2,004 \mathrm{a}$ \\
\hline NAUB & $1.86 \mathrm{a}$ & $31.3 \mathrm{a}$ & 2,079 & 1,754 & 2,884 & 1,203 & 2,194 & $2,023 \mathrm{a}$ \\
\hline Average & 1.96 & 29.4 & 1,975 & 1,580 & 2,043 & 1,579 & 2,394 & 1,914 \\
\hline $\mathrm{C}_{1}=\mathrm{NS}-\mathrm{CS}$ & ns & ns & $-3,005^{*}$ & ns & ns & ns & ns & ns \\
\hline $\mathrm{C}_{2}=$ WANC - NANC & ns & ns & ns & ns & ns & $\mathrm{ns}$ & $\mathrm{ns}$ & ns \\
\hline $\mathrm{C}_{3}=\mathrm{PP}-\mathrm{UB}$ & $\mathrm{ns}$ & ns & ns & $1,435^{*}$ & ns & ns & $\mathrm{ns}$ & ns \\
\hline $\mathrm{C}_{4}=\mathrm{WAPP}-\mathrm{NAPP}$ & $\mathrm{ns}$ & ns & $\mathrm{ns}$ & ns & ns & $\mathrm{ns}$ & ns & $\mathrm{ns}$ \\
\hline $\mathrm{C}_{5}=$ WAUB - NAUB & ns & ns & $\mathrm{ns}$ & $-854^{*}$ & ns & ns & $\mathrm{ns}$ & $\mathrm{ns}$ \\
\hline$\overline{\mathrm{CV}}(\%)$ & 40.1 & 33.9 & 35.8 & 41.4 & 85.7 & 57.8 & 38.6 & 41.0 \\
\hline
\end{tabular}

$\mathrm{C}_{1}, \mathrm{C}_{2}, \mathrm{C}_{3}, \mathrm{C}_{4}$ e $\mathrm{C}_{5}$ - Contrasts 1, 2, 3, 4, and 5, respectively; NS - Non-cultivated SS (WANC; NANC); CS - Cultivated SS (WAPP; NAPP; WAUB; NAUB); WANC - SS aerated and non-cultivated; NANC - SS non-aerated and non-cultivated; PP - SS cultivated with $P$. purpureum (WAPP; NAPP); UB - SS cultivated with $U$. brizantha (WAUB; NAUB); WAPP - SS aerated and cultivated with $P$. purpureum; NAPP - SS non-aerated and cultivated with $P$. purpureum; WAUB - SS aerated and cultivated with $U$. brizantha; NAUB - SS non-aerated and cultivated with $U$. brizantha.; $\mathrm{CV}$ - Coefficient of variation; ns - Not significant at 0.05 probability by $\mathrm{F}$ test; *, ** - Significant at 0.05 and 0.01 probability by $\mathrm{F}$ test, respectively. Average values followed by the same letter are not significant at 0.05 probability by Tukey test. 
Table 7: Metabolic $\left(\mathrm{qCO}_{2}\right)$ and microbial (qMIC) quotients of sewage sludge cultivated with P. purpureum or U. brizantha, with or without aeration

Metabolic Quotient $\left(\mathrm{mg} \mathrm{C}_{-} \mathrm{CO}_{2} \mathrm{~g}^{-1} \mathrm{MBC}^{-1}\right)$

Treataments / Contrasts

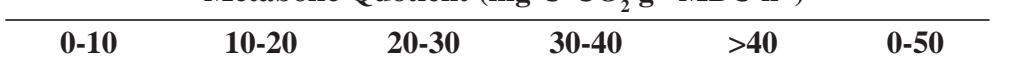

$0-10 \quad 10-20$

Microbial Quotient (\%)

\begin{tabular}{|c|c|c|c|c|c|c|c|c|c|c|c|c|}
\hline WANC & & & & & & & & & & & & \\
\hline WANC & 0.93 & 1.69 & 0.79 & 0.81 & 0.70 & $1.03 \mathrm{a}$ & 0.49 & 0.35 & 0.70 & 0.67 & 0.88 & $0.62 \mathrm{a}$ \\
\hline NANC & 1.25 & 1.26 & 1.50 & 1.39 & 1.17 & $1.51 \mathrm{a}$ & 0.57 & 0.58 & 0.67 & 0.41 & 0.60 & $0.57 \mathrm{a}$ \\
\hline WAPP & 0.81 & 0.64 & 0.74 & 0.95 & 0.99 & $0.75 \mathrm{a}$ & 0.87 & 0.85 & 0.76 & 0.55 & 0.71 & $0.74 \mathrm{a}$ \\
\hline NAPP & 0.88 & 1.50 & 1.30 & 1.13 & 0.64 & $1.04 \mathrm{a}$ & 0.86 & 0.49 & 0.33 & 0.33 & 0.87 & $0.59 \mathrm{a}$ \\
\hline WAUB & 1.07 & 1.97 & 1.47 & 0.87 & 0.90 & $1.27 \mathrm{a}$ & 0.59 & 0.31 & 0.66 & 0.87 & 0.98 & $0.68 \mathrm{a}$ \\
\hline NAUB & 0.87 & 1.00 & 1.43 & 1.29 & 0.84 & $1.01 \mathrm{a}$ & 0.67 & 0.59 & 0.96 & 0.39 & 0.74 & $0.66 \mathrm{a}$ \\
\hline Average & 0.97 & 1.34 & 1.21 & 1.07 & 0.87 & 1.10 & 0.68 & 0.53 & 0.68 & 0.54 & 0.80 & 0.64 \\
\hline $\mathrm{C}_{1}=\mathrm{NS}-\mathrm{CS}$ & ns & ns & ns & ns & ns & $\mathrm{ns}$ & $-0.87^{*}$ & ns & ns & ns & ns & ns \\
\hline $\mathrm{C}_{2}=$ WANC - NANC & ns & ns & ns & $-0.58^{* * *}$ & ns & ns & ns & ns & ns & ns & ns & ns \\
\hline $\mathrm{C}_{3}=\mathrm{PP}-\mathrm{UB}$ & ns & $\mathrm{ns}$ & ns & ns & $\mathrm{ns}$ & $\mathrm{ns}$ & $\mathrm{ns}$ & ns & ns & ns & ns & ns \\
\hline $\mathrm{C}_{4}=\mathrm{WAPP}-\mathrm{NAPP}$ & $\mathrm{ns}$ & $-0.86^{*}$ & ns & $-0.18^{*}$ & ns & ns & ns & ns & ns & ns & ns & ns \\
\hline $\mathrm{C}_{5}=$ WAUB $-\mathrm{NAUB}$ & $\mathrm{ns}$ & $0.97^{*}$ & ns & $\mathrm{ns}$ & ns & ns & $\mathrm{ns}$ & $-0.28^{*}$ & ns & ns & ns & ns \\
\hline $\mathrm{CV}(\%)$ & 36.9 & 36.9 & 56.3 & 22.3 & 39.0 & 41.0 & 34.5 & 44.4 & 82.3 & 59.9 & 38.6 & 29.7 \\
\hline
\end{tabular}

$\mathrm{C}_{1}, \mathrm{C}_{2}, \mathrm{C}_{3}, \mathrm{C}_{4}$ e $\mathrm{C}_{5}$ - Contrasts $1,2,3,4$, and 5, respectively; NS - Non-cultivated SS (WANC; NANC); CS - Cultivated SS (WAPP; NAPP; WAUB; NAUB); WANC - SS aerated and non-cultivated; NANC - SS non-aerated and non-cultivated; PP - SS cultivated with P. purpureum (WAPP; NAPP); UB - SS cultivated with U. brizantha (WAUB; NAUB); WAPP - SS aerated and cultivated with $P$. purpureum; NAPP - SS non-aerated and cultivated with P. purpureum; WAUB - SS aerated and cultivated with U. brizantha; NAUB - SS non-aerated and cultivated with $U$. brizantha.; CV - Coefficient of variation; ns - Not significant at 0.05 probability by F test; *, ** - Significant at 0.05 and 0.01 probability by F test, respectively. Average values followed by the same letter are not significant at 0.05 probability by Tukey test. 

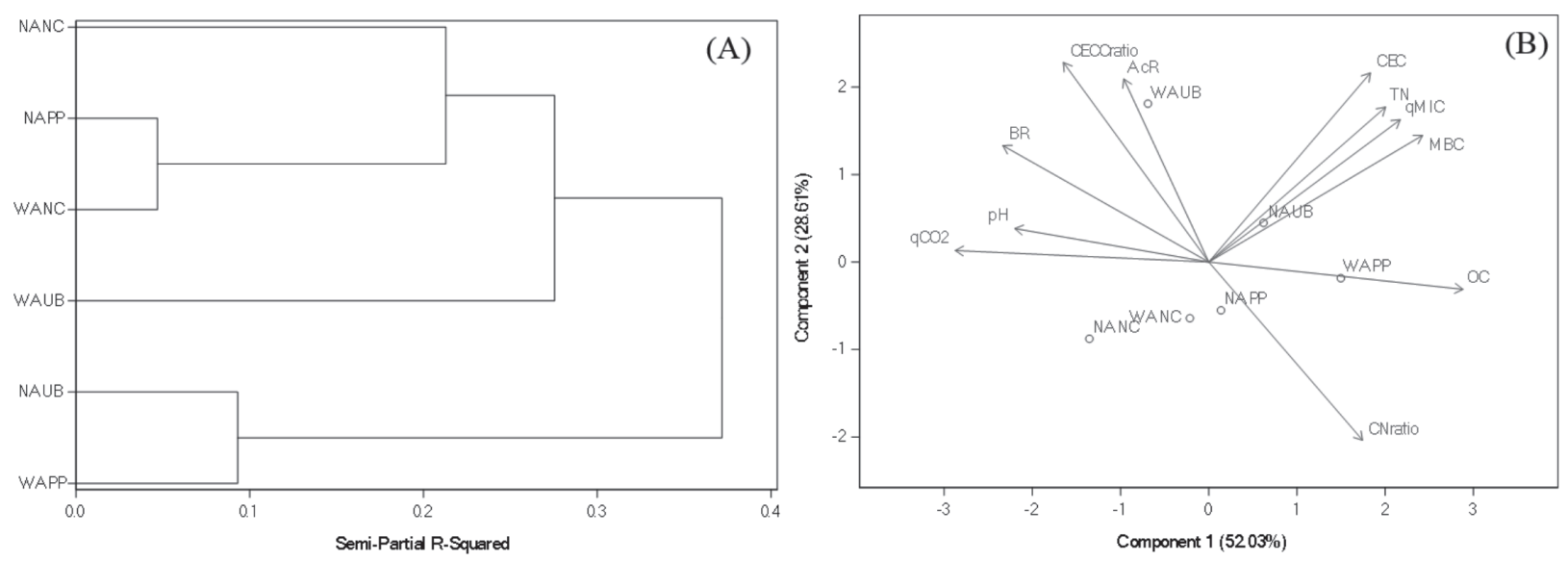

Figure 2: Dendrogram of the cluster analysis by Ward method (A) and biplot of principal component analysis (PCA) (B) of chemical and microbial attributes of sewage sludge cultivated with $P$. purpureum and $U$. brizantha in the presence or absence of aeration. WANC - SS aerated and non-cultivated; NANC - SS non-aerated and non-cultivated; WAPP - SS aerated and cultivated with $P$. purpureum; NAPP - SS non-aerated and cultivated with $P$. purpureum; WAUB - SS aerated and cultivated with $U$. brizantha; NAUB - SS non-aerated and cultivated with U. brizantha; OC - Organic carbon; TN; Total Nitrogen; CEC - Cation Exchange Capacity; BR - Basal Respiration; CR - Cumulative Respiration; MBC - Microbial Biomass Carbon; qCO2 - Metabolic Quotient; qMIC Microbial Quotient.

this treatment. The $\mathrm{C} / \mathrm{N}$ ratio was the most influential attribute on the NAPP treatment. The CEC/C ratio and the accumulated respiration were the attributes that influenced the WAUB treatment. The highest index value in the WAUB treatment induces a great stabilization of the sewage sludge, despite the high microbial activity, demonstrating that the organic matter is not completely matured in relation to the other treatments. The lower $\mathrm{pH}$, basal respiration, and $\mathrm{qCO}_{2}$ values and the highest $\mathrm{OC}$ concentration show the highest stabilization of organic matter of sewage sludge aerated and cultivated with $P$. purpureum .

Using both statistical methods (univariate and multivariate analyses), we can infer that was a higher quality of the organic fertilizer when the sewage sludge was aerated and cultivated with $P$. purpureum and lower when it was not aerated and cultivated. In addition, this technique can be used to produce an organic fertilizer with great features to be used as substrate for plants, source of nutrients, and soil conditioner, considering that the initial heavy metals concentration (Table 1) was below the established by the legislation (Brasil, 2020a).

\section{CONCLUSIONS}

The species $U$. brizantha and $P$. purpureum have potential for direct cultivation in sewage sludge. However, the $P$. purpureum root system provides better conditions for stabilization and maturation of the organic matter of sewage sludge.

The sewage sludge aerated and cultivated with $P$. purpureum provides the formation of organic fertilizer with greater maturation of the organic matter, enhancing the use of this by-product in farming and forest areas. Even though, further studies must be carried out to investigate the influence of cultivation and aeration of sewage sludge on heavy metals and organic pollutants.

\section{ACKNOWLEGEMENTS, FINANCIAL SUPPORT AND FULL DISCLOSURE}

The authors would like to thank COPASA for granting the sewage sludge used. This study was financed in part by the Coordenação de Aperfeiçoamento de Pessoal de Nível Superior - Brasil (CAPES) - Finance Code 001.

The authors would like to inform that there is no conflict of interests in carrying the research and publishing the manuscript.

\section{REFERENCES}

Alcarde JC (2009) Manual de análise de fertilizantes. Piracicaba, FEALQ. 259p.

Alvarenga AC, Cardoso PHS, Coutinho MAN, Oliveira ALG \& Sampaio RA (2018) Produção de biomassa e fitoextração de $\mathrm{Cu}$ e Zn pelo capim-elefante cultivado em lodo de esgoto puro. Revista Engenharia na Agricultura, 26:473-482.

Alvarenga AC, Cardoso PHS, Cunha IGS, Gonçalves PWB \& Sampaio RA (2019) Extração de arsênio em lodo de esgoto pelo processo de fitoextração. Revista Engenharia na Agricultura, 27:565-573.

Alvarenga AC, Sampaio RA, Pinho GP, Cardoso PHS, Sousa IP \& Barbosa MHC (2017) Phytoremediation of chlorobenzenes in sewage sludge cultivated with Pennisetum purpureum at different times. Revista Brasileira de Engenharia Agrícola e Ambiental, 21:573-578.

Alves TS, Campos LL, Elias Neto N, Matsuoka M \& Loureiro MF (2011) Biomassa e atividade microbiana de solo sob vegetação nativa e diferentes sistemas de manejos. Acta Scientiarum. Agronomy, 33:341-347.

Rev. Ceres, Viçosa, v. 68, n.5, p. 471-483, sep/oct, 2021 
Awasthi MK, Wang Q, Chen H, Wang M, Awasthi SK, Ren X, Cai H, Li R \& Zhang Z (2018) In-vessel co-composting of biosolid Focusing on mitigation of greenhouse gases emissions and nutrients conservation. Renewable Energy, 129:814-823.

Braga RR, Santos JB, Zanuncio JC, Bibiano CS, Ferreira EA, Oliveira MC, Silva DV \& Serrão JE (2016) Effect of growing Brachiria brizantha on phytoremediation of picloram under different pH environments. Ecological Engineering, 94:102106

Brasil (2020a) Resolução n 498, de 19 de agosto de 2020. Define critérios e procedimentos para produção e aplicação de biossólido em solos, e dá outras providências. DOU, 21/08/2020, Section 1, p. 265 .

Brasil (2020b) Instrução Normativa ${ }^{\circ}$ 61, de 08 de julho de 2020 Estabelece as regras sobre definições, exigências, especificações, garantias, tolerâncias, registro, embalagem e rotulagem dos fertilizantes orgânicos e dos biofertilizantes, destinados à agricultura. DOU, 15/07/2020, Section 1.

Cai QY, Mo CH, Wu QT, Zeng QY, Katsoyiannis A \& Férard JF (2007a) Bioremediation of polycyclic aromatic hydrocarbons (PAHs)-contaminated sewage sludge by different composting processes. Journal of Hazardous Materials, 142:535-542.

Cai QY, Mo CH, Wu QT, Zeng QY \& Katsoyiannis A (2007b) Concentration and speciation of heavy metals in six different sewage sludge-composts. Journal of Hazardous Materials, 147:1063-1072.

Carvalhais LC, Dennis PG, Fedoseyenko D, Hajirezaei MR, Borriss R \& Von Wirén N (2011) Root exudation of sugars, amino acids, and organic acids by maize as affected by nitrogen, phosphorus, potassium, and iron deficiency. Journal of Plant Nutrition and Soil Science, 174:3-11.

Chikere CB \& Fenibo EO (2018) Distribution of PAH-ring hydroxylating dioxygenase genes in bacteria isolated from two illegal oil refining sites in the Niger Delta, Nigeria. Scientific African, 1:e00003.

Costa OV, Cantarutti RB, Fontes LEF, Costa LM, Nacif PGS \& Faria JC (2009) Estoque de carbono do solo sob pastagem em área de tabuleiro costeiro no sul da Bahia. Revista Brasileira de Ciência do Solo, 33:1137-1145.

Ekinci K, Tosun I, Inan SA, Memici M \& Kumbul BS (2017) Design and construction of a pilot scale aerated static pile composting systems. Scientific Papers. Series E. Land Reclamation, Earth Observation \& Surveying, Environmental Engineering, 6:7-12.

Flores RA, Urquiaga S, Alves BJR, Collier LS \& Boddey RM (2012) Yield and quality of elephant garss biomass produced in the cerrados region for bioenergy. Engenharia Agrícola, 32:831839.

Godoy LC (2013) A logística na destinação do lodo de esgoto. Revista Científica On-line: Tecnologia, Gestão e Humanismo, 2:79-90.

Golbaz S, Zamanzadeh MZ, Pasalari H \& Farzadkia M (2020) Assessment of co-composting of sewage sludge, woodchips, and sawdust: feedstock quality and design and compilation of computational model. Environmental Science and Pollution Research, 28:12414-12427.

INMET - Instituto Nacional de Meteorologia. BDMEP: Banco de dados históricos. Available at: <http://www.inmet.gov.br/portal/ $>$. Accessed on: August 1 ${ }^{\text {st }}, 2017$

Kang DJ, Seo YJ, Saito T, Suziki H \& Ishii Y (2012) Uptake and translocation of cesium-133 in napiergrass (Pennisetum purpureum Schum.) under hydroponic conditions. Ecotoxicology and Environmental Safety, 82:122-126.
Li W, Xu L, Wu J, Ma L, Liu M, Jiao J, Li H \& Hu F (2015) Effects of indole-3-acetic acid (IAA), a plant hormone, on the ryegrass yield and the removal of fluoranthene from soil. International Journal of Phytoremediation, 17:422-428.

Li X, Geng X, Xie R, Fu L, Jiang J, Gao L \& Sun J (2016). The endophytic bacteria isolated from elephant grass (Pennisetum purpureum Schumach) promote plant growth and enhance salt tolerance of Hybrid Pennisetum. Biotechnology for Biofuels, $9: 1-12$.

Lima CC, Mendonça ES, Silva IR, Silva LHM \& Roig A (2009) Caracterização química de resíduos da produção de biodiesel compostados com adição mineral. Revista Brasileira de Engenharia Agrícola e Ambiental, 13:334-340.

Melo W, Delarica D, Guedes A, Lavezzo L, Donha R, Araújo A, Melo G \& Macedo F (2018) Ten years of application of sewage sludge on tropical soil. A balance sheet on agricultural crops and environmental quality. Science of The Total Environment, 643:1493-1501.

Morais RF, Quesada DM, Reis VM, Urquiaga S, Alves BJR \& Boddey RM (2012) Contribution of biological nitogen fixation to Elephant grass (Pennisetum purpureum Schum.). Plant and Soil, 356:23-24.

Moretti SML, Bertoncini EI \& Abreu Junior CH (2015) Composting sewage sludge green waste from tree pruning. Scientia Agricola, 72:432-439.

Nikaeen M, Nafez AH, Bina B, Nabavi BF \& Hassanzadeh A (2015) Respiration and enzymatic activities as indicators of stabilization of sewage sludge composting. Waste Management, 39:104-110

Oliveira ESA, Cardoso PHS, Sousa IP, Alvarenga AC, Rodrigues MN \& Sampaio RA (2018) Copper and zinc fractionation in biosolid cultivated with Pennisetum purpureum in different periods. Revista Brasileira de Engenharia Agrícola e Ambiental, 22:3-9.

Oliveira FC, Faria MF, Bertoncini EI, Sato MIZ, Hachich EM, Guerrini IA, Passos JRS, James JN, Harrison RB, Feitoza TG, Chiaradia JJ, Abreu-Junior CH \& Moraes LPF (2019) Persistence of fecal contamination indicators and pathogens in class B biosolids applied to sugarcane fields. Journal of Environmental Quality, 48:526-530.

Pimentel-Gomes F (2009) Curso de estatística experimental. 15 $5^{\text {th }}$ ed. Piracicaba, FEALQ. 451p.

R development core team (2017) R: A Language and environment for statistical computing. Vienna, R Foundation for Statistical Computing. Available at: https://www.r-project.org/. Accessed on: October $1^{\text {st }}, 2017$.

Sanchez-Monedero MA, Cayuela ML, Roig A, Jindo K \& Bolan MN (2018) Role of biochar as an additive in organic waste composting. Bioresource Technology, 247:1155-1164.

SAS Institute Inc. (2002) Statistical Analysis System user's guide. Version 9.0. Cary, Statistical Analysis System Institute. 513p.

Shen H, Wang X, Shi W, Cao Z \& Yan X (2001) Isolation and identification of specific root exudates in elephant grass in response to mobilization of iron- and aluminum-phosphates. Journal of Plant Nutrition, 24:1117-1130.

Silva EE, Azevedo PHS \& De-Polli H (2007a) Determinação da Respiração Basal (RBS) e Quociente metabólico do Solo ( $\mathrm{qCO}_{2}$ ). Seropédica, Embrapa Agrobiologia. 4p. (Technical Bulletin, 99).

Silva EE, Azevedo PHS \& De-Polli H (2007b) Determinação do Carbono da Biomassa Microbiana do Solo (BMS-C). Seropédica, Embrapa Agrobiologia. 6p. (Technical Bulletin, 98). 
Silva MC, Figueiredo AF, Andreote FD \& Cardoso EJ (2013) Plant growth promoting bacteria in Brachiaria brizantha. World Journal of Microbiology and Biotechnology, 29:163-171.

Silva TO, Santos AR, Santos JHS \& Silva JO (2005) Produção do capim marandu submetido a doses de nitrogênio em um Latossolo Amarelo. Agropecuária Técnica, 26:29-35.

Souza RAS, Bissani CA, Tedesco MJ \& Fontoura RC (2012) Extração sequencial de zinco e cobre em solos tratados com lodo de esgoto composto de lixo. Química Nova, 35:308-314.

Sparling GP \& West AW (1988) A Direct Extraction method to estimate soil microbial $\mathrm{C}$ : Calibration in situ using microbial respiration and 14C labelled cells. Soil Biology and Biochemistry, 20:337-343.

Tian W, Zhao J, Zhou Y, Qiao K, Jin X \& Liu Q (2017) Effects of root exudates on gel-beads/reeds combination remediation of high molecular weight polycyclic aromatic hydrocarbons. Ecotoxicology and Environmental Safety, 135:158-164.

Tontti T, Poutiainen H \& Heinonen Tanski H (2017) Efficiently treated sewage sludge supplemented with nitrogen and potassium is a good fertilizer for cereals. Land Degradation \& Development, 28:742-751.

Umar ZD, Azwady N, Aziz A, Zulkifli SZ \& Mustafa M (2018) Effective phenanthrene and pyrene biodegradation using Enterobacter sp. MM087 (KT933254) isolated from used engine oil contaminated soil. Egyptian Journal of Petroleum, 27:349359
Videira SS, Oliveira DM, Morais RF, Borges WL, Baldani VLD \& Baldani JI (2012) Genetic diversity and plant growth promoting traits of diazotrophic bacteria isolated from two Pennisetum purpureum Schum. genotypes grown in the field. Plant and Soil, 356:51-66.

Vieira RF \& Pazianotto RAA (2016) Microbial activities in soil cultivated with corn and amended with sewage sludge. Springer Plus, 5:1844-1860.

Villanueva FCA, Boaretto AE, Firme LP, Muraoka T, Nascimento Filho VF \& Abreu Junior CH (2012) Mudanças químicas e fitodisponibilidade de zinco estimada por método isotópico, em solo tratado com lodo de esgoto. Química Nova, 35:1348-1354.

Yuan J, Chadwick D, Zhang D, Li G, Chen S, Luo W, Du L, He S \& Peng S (2016) Effects of aeration rate on maturity and gaseous emissions during sewage sludge composting. Waste Management, 56:403-410.

Zhang L \& Sun X (2016) Influence of bulking agents on physical, chemical, and microbiological properties during the two-stage composting of green waste. Waste Management, 48:115-126.

Zhang X, Xia H, Li Z, Zhuang P \& Gao B (2010) Potencial of four forage grasses in remediation of $\mathrm{Cd}$ and $\mathrm{Zn}$ contaminated soils. Bioresource Technology, 101:2063-2066. 